\title{
“音”による食感の可視化
}

\section{Objective Evaluation of Crispy and Crunchy Textures of Foods by Acoustic Analysis}

\section{杉山妙}

日清オイリオグループ株式会社 中央研究所

T 235-8558

神奈川県横浜市磯子区新森町 1 番地

Tae SUGIYAMA

The Nisshin OilliO Group, Ltd.

Central Research Laboratory

1 Shinmori-cho, Isogo-ku Yokohama, Kanagawa 235-8558, Japan

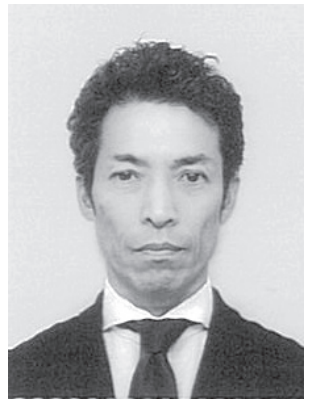

村野 賢博

日清オイリオグループ株式会社

中央研究所

T 235-8558

神奈川県横浜市磯子区新森町 1 番地

Yoshihiro MURANO

The Nisshin OilliO Group, Ltd.

Central Research Laboratory

1 Shinmori-cho, Isogo-ku Yokohama, Kanagawa 235-8558, Japan

論文要旨：食品の「おいしさ」には，人の五感で知覚される味・香り・食感・外観といった様々な要素が 複雑に関わっている。揚げ物やスナック菓子等の固形食品の「おいしさ」評価では, サクサク・パリパリと いう“音”で表現される食感 (テクスチャー) が重要であり,これを客観的に評価する手法が開発されている。 本稿では, 筆者らの研究グループが開発した「食感音響評価システム」による, 咀嚼を模した食品破砕とそ の破砕音の解析結果を中心に, “音”による食感評価方法について解説する。

\begin{abstract}
Palatability of foods depends on many factors, such as flavor, texture, and appearance. Textures such as crispness, crunchiness, hardness, and fragility are essential in many foods and evaluated by sensory tests in general. Although food scientists and engineers have attempted objective evaluations of the characteristic textures of different foods, an optimal method for the texture evaluation is yet to be developed. Here, we focused on the theory that texture can be evaluated based on the sound created during mastication. We developed a device mechanically capable of crushing foods. By combining this food crushing device with a method to analyze the crushing sounds, we aimed to construct an objective system for texture evaluation. In this report, we introduce our system and some acoustic analysis results. It is showed that the sounds of food crunched are useful to indicate its crispness objectively.
\end{abstract}

Key words: food texture, acoustic analysis, mastication sounds, onomatopoeia

\section{1 はじめに}

人が食品を食べるときに感じる「おいしさ」は, 視覚・ 嗅覚・味覚・聴覚・触覚の五感によって知覚され, 総合 的に判断されている。高橋ら ${ }^{1)}$ は,「おいしさ」にかか わる食品自体の状態を化学的要因と物理的要因に大別し ている。化学的要因には味と香りがあり，物理的要因に は, テクスチャー, 外観, 音, 温度があるとしている。 柳本 ${ }^{2)}$ は, 食べ物の「おいしさ」にかかわる感覚特性 を調べた結果, 固形食品ではテクスチャーの貢献度が高 く, 液状食品では味の貢献度が高いことを示している。 これらのことから, 食感（テクスチャー）を可視化し,
正しく客観的に評価する試みは，「おいしさ」を創造・ 比較する上で重要な技術領域となっている。

早川 ${ }^{3)}$ は, 官能評価に用いられるテクスチャー語彙 の構造を解析し, 言語が異なっても, 破砕の表現および 空気による軽さの表現が主要な構成要素であるという共 通点を見出している。また, 日本語のテクスチャー用語 は, 445 語と他言語に比較して多いが，そのうち約 7 割 を擬音語・擬態語（オノマトペ）が占めることに起因す ると推察している。例えば, 揚げ物の「おいしさ」を表 現するサクサク・サクッ・カリッ・パリパリ等のテクス チャー用語はすべて擬音語であり，いずれも極めて認知 度が高い3)。このことから, 食品の「おいしさ」と“音” で表現される食感（テクスチャー）が密接な関係にある ことが分かる。 
また, テクスチャー用語は商品パッケージや広告等で, 消費者の感性に訴えて購買意欲を高めるためにも活用さ れている。オノマトペによって, 商品の食感を直感的に 伝えることで「おいしさ」を感じさせる効果や，商品へ の期待感と実際の食感との齟齙を軽減する効果が見込ま れている4)。また，広告では適切なオノマトぺを使用す ることによって，インパクトを与えて記憶に残らせる効 果や, 商品の差別化・識別化に繋げる効果も期待されて いる ${ }^{5)}$ 。

現在, 食品の研究開発における食感の評価方法として は，実際に食べて評価を行う官能評価試験が一般的であ る。官能評価試験は実感に即して高感度である一方，熟 練技術を必要とし，日間・拠点間比較が難しいという課 題もある。そこで, 誰でも再現性高く評価できる客観的 な方法として，様々な機械・装置が開発されてきた。食 品を押し潰して圧力や振動等を測定するレオメーターや テクスチャーアナライザー等の機器や, 食品の構造を観 察できるデジタルマイクロスコープが市販されている が，多様な食感を実感どおりに評価できる完璧な方法は 未だない。

食感 (テクスチャー) の定義として, 日本産業規格 (JIS Z8144 官能評価分析一用語) では, (食品の) テクスチャー は「口内で知覚できる食品の物理的特性, 又は触覚, 視 覚及び聴覚によって判断できる食品の構造若しくは組成 に関する特性」とされている。国際標準化機構（ISO 11036：2020）では, texture は「all the mechanical, geometrical and surface attributes of a product perceptible by means of mechanical, tactile and, where appropriate, visual and auditory receptors」(力学的, 触覚的, およ び適切な場合は視覚的および聴覚的に知覚できる，製品 の力学的, 幾何学的および表面の特性すべて) とされて いる。

上記定義でも触れたように，食感には聴覚的に知覚さ れる特性も含まれることから，食べたときの“音”が「お いしい」と認識される食品は，「おいしい」食感を有し ていると言うことができる。“音”は，食品破壊時の振 動の伝播によるものであり，その破壊特性はすなわちテ クスチャーそのものである ${ }^{6)}$ 。したがって，咀嚼などに よる食品破砕時に発生する “音”を解析することは, 食 感を評価する上で重要である。

食感や「おいしさ」の知覚における“音”の重要性を 示す研究は, 1960 年代前半には Drake ${ }^{7)} に よ り$ 行われ, 1970～90 年代にはVickers ${ }^{8,9)}$, Lee $^{10,11)}$, Dacremont ${ }^{12,13)}$, Duizer $^{14)}$ らにより数多く報告されている。Dacremont $ら^{12,13)}$ は咀嚼音を FFT 解析し, アーモンドや人参等 の食品を 3 種類の食感に分類している。Duizer ら ${ }^{14)}$ は
スナック菓子, Lee ら ${ }^{10,11)}$ はポテトチップスの咀嚼音 を FFT 解析し多変量解析を行っている。また, Zampini ら ${ }^{15)}$ は， ポテトチップスの咀嚼音のうち高周波成分 または全周波数の音圧レベルを増幅してフィードバック することで, クリスプネス（パリパリした食感）が強く 感じられることを発見し，2008 年にはイグノーベル賞 を受賞している。

以上のように, 食品の「おいしさ」の構成要素として 食感（テクスチャー）が重要であり, 食感は咀嚼音に よって特徵づけることができる。このことから, 食感を 客観的に評価するために, 機械的に咀嚼を再現し, この とき発生する破砕音や振動を解析する手法が試みられて いる 16-18)。

本稿では, 筆者らの研究グループが開発した「食感音 響評価システム」による咀嚼を模した食品破砕とその破 砕音の解析結果を中心に, “音”による食感評価方法に ついて解説する。

\section{2 “音”による食感評価}

\section{$2 \cdot 1$ 食感音響評価システム}

実際に人が食べたときの音（咀嚼音）は，耳に伝わる 経路によって気導音と骨導音に分けられる。気導音は空 気を伝播して鼓膜に達する音で, 食べている本人だけで なく周囲の人にも聞こえ，通常のマイクで録音できる。 骨導音は歯から骨を経て直接内耳に伝わる音で, 食べて いる本人にしか聞こえないが，額や耳の後ろ等に装着し 振動を検知するコンタクトマイクがあれば録音できる。 しかし，人が食べたときの咀嚼音は，口に含む量や噛み 方, 頭蓋骨の大きさ等の影響を受けるため, 音量や音質, リズムには個人差があり，同じ食品であっても発生する 音も知覚する音も人それぞれ異なる。したがって, 客観 的に評価するためには機械的に咀嚼を再現したときの音 （破砕音）を解析する必要がある。

筆者らは, 食品を再現性良く破砕し録音する装置（Fig. 1）と，破砕音から食感を評価する音響解析ソフトから 構成される「食感音響評価システム」を開発し, 評価対 象食品の食感（テクスチャー）評価を行っている ${ }^{19)}$ 。 本システムは, 食品を試料台に載せてスイッチを押すと, エア駆動によって静かに試料台が上昇する。食品は, 上 部に固定してあるヒトの歯を模した破砕歯に当たり，押 し潰される。そのとき発生した音（破砕音）を高性能マ イクで収録し, 音響解析ソフトを用いて音量・音質を表 す各指標を算出する。それらと, サクサク感等の官能評 価結果とを予妏応付けておくことで, 以降は本システ ムによって食感を客観的に数值化できる。なお，本シス テムの破砕音は気導音であり，骨導音は加味されていな 


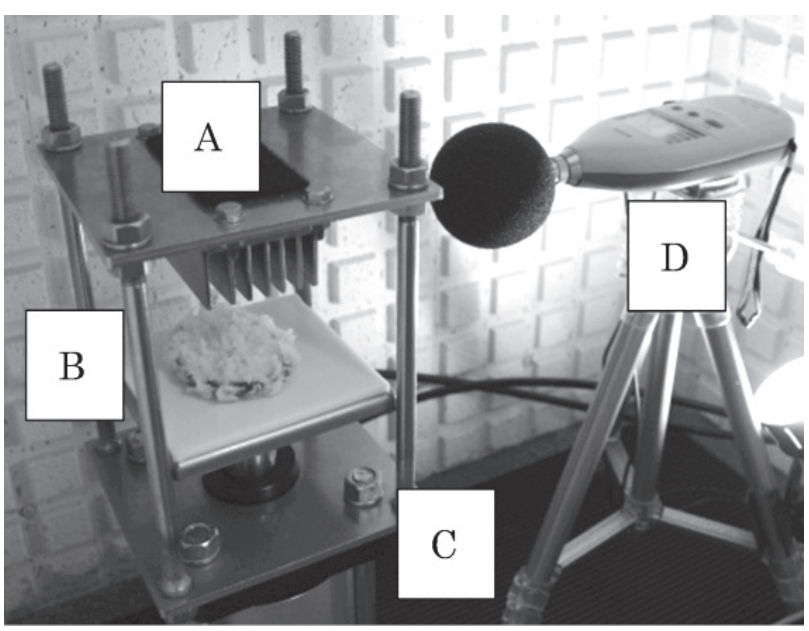

Fig. 1 Device to cut and crunch foods. (A) "Artificial teeth" : for cutting and crunching samples, (B) Sample stage, (C) Air cylinder, (D) Microphone.

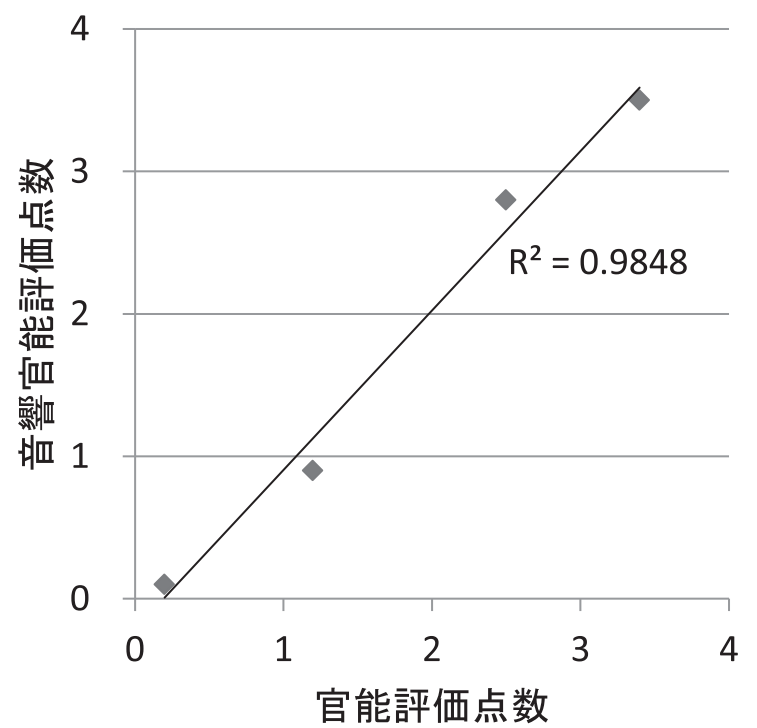

Fig. 2 "Acoustic" and actual scores in sensory evaluation test.

いが, 破砕音を聞いたときにイメージした食感の点数(音 響官能評価点数）と，実際に食べたときの官能評価点数 が高い相関を示すことが確認できている（Fig. 2)。した がって, 破砕音の解析により, 実際の食感を評価するこ とができる。

破砕音は，様々な周波数や音圧を含んだ複合音であ る。周波数解析には FFT 法などの定幅分析と, オクター ブ分析などの定比幅分析がある。人の耳の周波数分析機 能は等比的であることから，本システムでは音量の指標 として，1/3オクターブ分析にて音圧レベル（単位： $\mathrm{dB})$ という物理量を算出した。また，音質の指標とし てシャープネスとラフネスを用いた。どちらも人の耳に どのように聞こえるかを考慮した心理音響評価量であ り, コンサートホールの設計などにも利用されている。

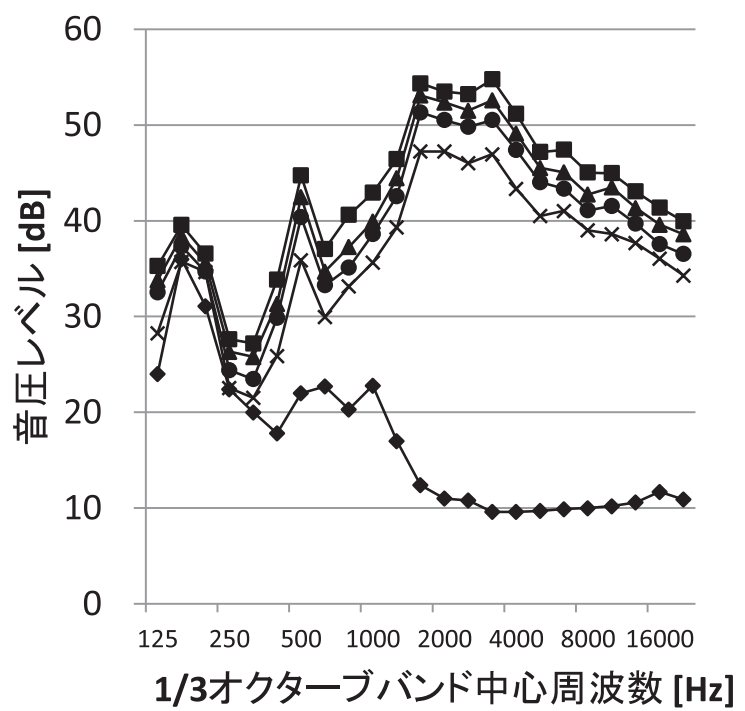

Fig. 3 1/3 octave-band analysis of Japanese croquette. Number of days of frozen storage $\times$; 11) and background noise

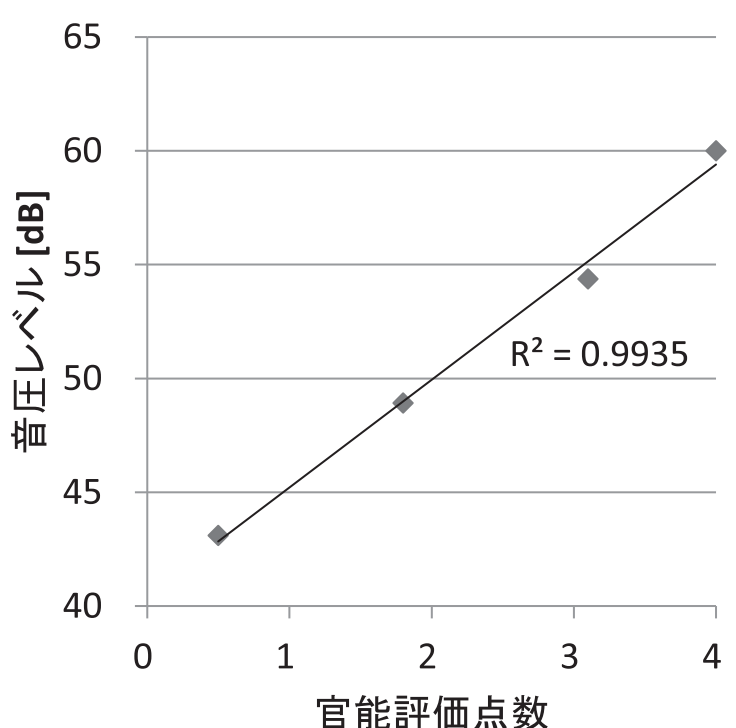

Fig. 4 Correlation between sound pressure levels and scores in sensory evaluation test.

シャープネス（単位：acum）は音の甲高さを表し，音 の高低バランスが高音域側に偏ったときに大きな值をと る。ラフネス（単位：asper）は音の粗さ感を表し, 音 の大きさ（ラウドネス, 単位：sone）や周波数が短い周 期（毎秒 70 回）で変動するときに最大となる。この変 調周波数は，音の変動は分かっても一つ一つの音を聞き 分けられないレベルであり，例えば，毎秒 4 回では音を 聞き分けられて変動感を感じ, 毎秒 200 回では変動があ ることも分からず滑らかに聞こえるという, 人の耳の特 性が考慮されている。

\section{$2 \cdot 2$ 揚げ物の評価事例}

「食感音響評価システム」を用いた破砕音の音響解析 


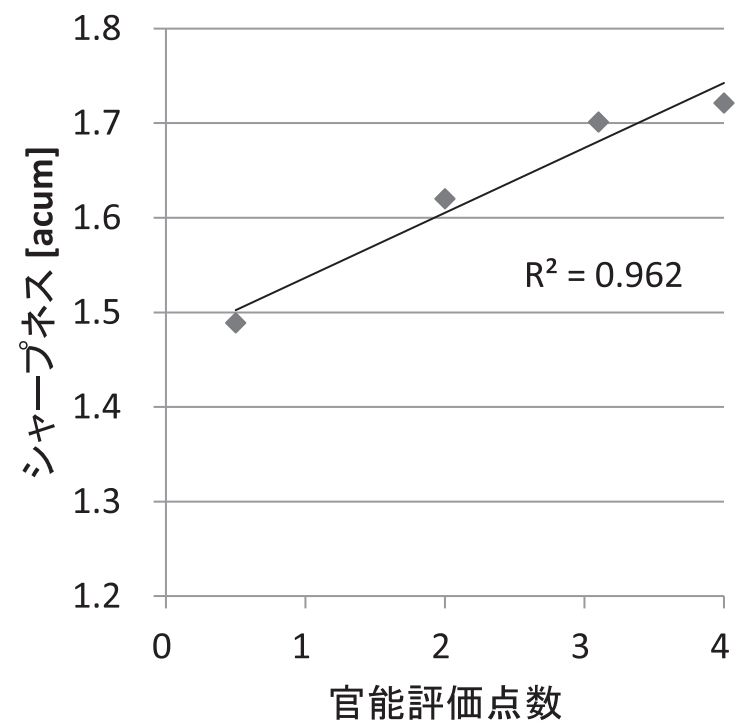

Fig. 5 Correlation between sharpness and scores in sensory evaluation test.

結果と食感の相関について事例を示す。コロッケの冷凍 保存試験では，破砕音の大きさ（音圧レベル）はいずれ の周波数带域においても日数経過に伴い低下寸る傾向が 見られる（Fig. 3）。また，保存日数によらず分布割合が 大きい $1,600 \sim 3,150 \mathrm{~Hz}$ 帯域の合成レベル（dB の和）を 算出すると, サクサク感の官能評価点数と高い相関を示 す (Fig. 4)。同様に, 音質の指標であるシャープネスと ラフネスも, 食感官能評価点数と高い相関を示す（Figs.

$5,6)$ 。

コロッケ等の揚げ物では，調理工程で衣側から水分が 抜けて，フライ油脂に置換される。出来立ての揚げ物は サクサクで油っこくないが，その食感を長時間にわたり 維持することは難しい。保存中に食感が劣化していく主 な原因は，揚げ物の内側から衣部への経時的な水分移行 であり，フライ油脂によっては劣化の進行を抑制できる ことが報告されている ${ }^{20,21)}$ 。そこで，2 種類の油脂（大 豆油，パームオレイン油）で調理したコロッケを例に， 冷凍保存による食感変化を経時的に比較した。官能評価

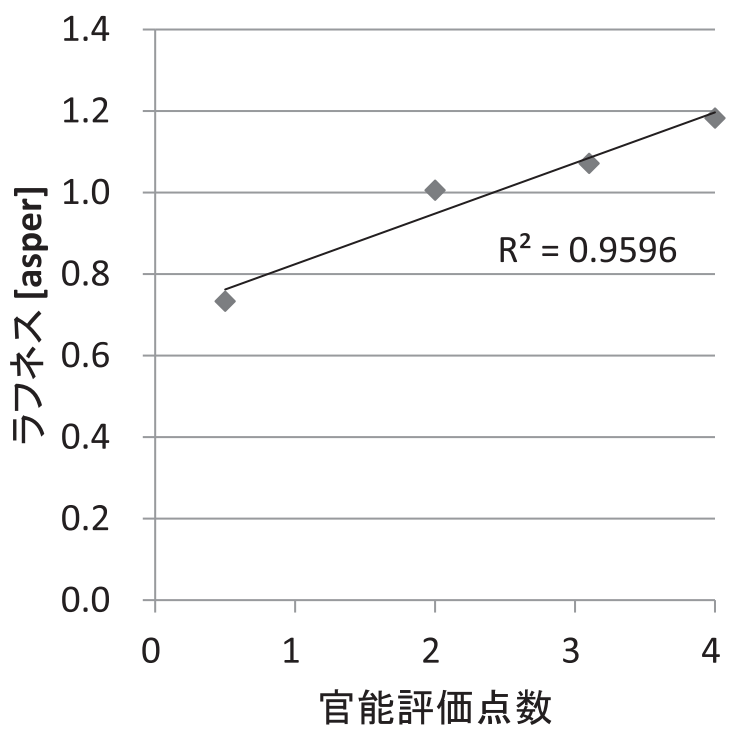

Fig. 6 Correlation between roughness and scores in sensory evaluation test.

結果からは, 大豆油よりもパームオレイン油で調理した コロッケの方がサクサク感を維持することが示されてい る。これらの破砕音の音響解析を行うと, パームオレイ ン油で調理したコロッケでは音圧レベル・シャープネス・ ラフネスの経時変化が緩やかなことが分かる（Table 1)。このように，音響解析によって冷凍保存に適した フライ油脂の選択を客観的に行うこともできる。

\section{$2 \cdot 3$ スナック菓子の評価事例}

破砕音の音響解析結果と食感の相関は, 評価対象の食 品によって異なる。その評価事例として，あるスナック 菓子では標準品 $\mathrm{a}$ と比較品 $\mathrm{b}, \mathrm{c}$ の外観形状が等しく, 音圧レベルの差異が小さいが（Fig. 7 (A)), 比較品 b のシャープネスは小さく, ラフネスは大きいという音響 解析結果が得られている (Fig. 7 (B)，(C))。このとき の官能評価結果から，シャープネスはサクサク感・軽さ と, ラフネスはガリガリ感・かたさとの相関が示唆され ている。したがって，食感を評価するためには音量だけ でなく音質も重要であると言える。ただし，各指標と食

Table 1 Actual score in sensory evaluation test and results of acoustic analysis.

\begin{tabular}{|c|c|c|c|c|c|}
\hline & フライ油脂 & 調理直後 & 保存 4 日目 & 保存 7 日目 & 保存 11 日目 \\
\hline \multirow{2}{*}{ 食感官能試験点数 } & 大豆油 & 4.0 & 3.1 & 2.0 & 0.5 \\
\hline & パームオレイン油 & 4.0 & 3.4 & $2.8^{* *}$ & 1.0 \\
\hline \multirow{2}{*}{$\begin{array}{c}\text { 音圧レベル } \\
\text { [dB] }\end{array}$} & 大豆油 & 59.4 & 57.6 & 55.7 & 52.2 \\
\hline & パームオレイン油 & 59.3 & $58.8 * * *$ & $57.5 * * *$ & $52.6 *$ \\
\hline \multirow{2}{*}{$\begin{array}{c}\text { シャープネス } \\
\text { [acum] }\end{array}$} & 大豆油 & 1.71 & 1.58 & 1.49 & 1.44 \\
\hline & パームオレイン油 & 1.71 & $1.62^{*}$ & $1.56^{* *}$ & $1.46^{*}$ \\
\hline \multirow{2}{*}{$\begin{array}{l}\text { ラフネス } \\
\text { [asper] }\end{array}$} & 大豆油 & 1.11 & 0.91 & 0.77 & 0.72 \\
\hline & パームオレイン油 & 1.12 & $0.98 * *$ & $0.93 * * *$ & $0.82 *$ \\
\hline
\end{tabular}


(A)

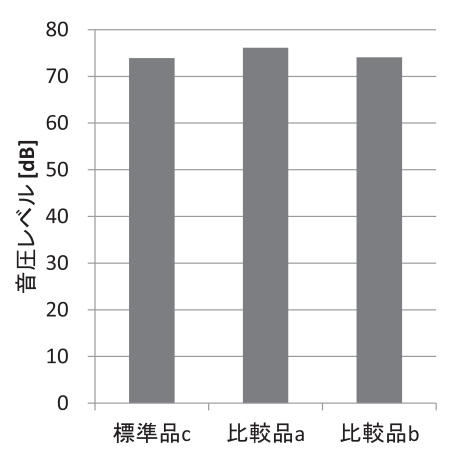

(B)

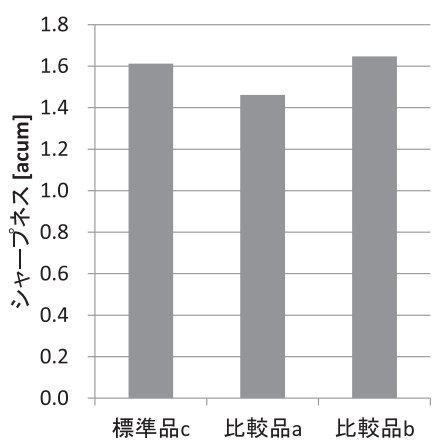

(C)

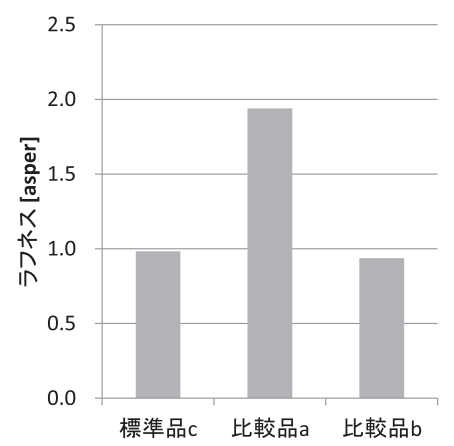

Fig. 7 Acoustic analysis of snacks (A) Sound pressure level, (B) Sharpness, (C) Roughness.

\begin{tabular}{|c|c|c|}
\hline$A$ & B & C \\
\hline & & \\
\hline & & \\
\hline
\end{tabular}

Fig. 8 Three kinds of potato chips: A, B, and C.

(A)

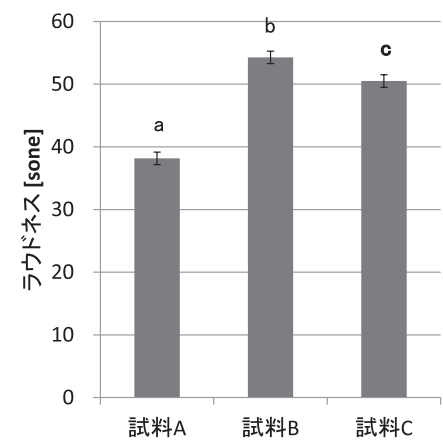

(B)



(c)



Fig. 9 Acoustic analysis of potato chips (A) Loudness, (B) Sharpness, (C) Roughness. Letters indicate statistically significant differences $(p<0.05)$.

感の対応付けは食品毎に異なるため，その都度検討が必 要である。

また, 市販のポテトチップス 3 種の食感評価事例を示 す。試料 A は標準的な平らで薄い形状でパリッとした 食感，試料 B はウェーブカットで厚いが割れやすいサ クッ・ホロッとした食感, 試料 C は堅くてカリカリと した食感である（Fig. 8)。音量の指標として，音圧レベ ル（物理量）の代わりにラウドネス（心理音響評価量） を用いて, 破砕音の音響解析を実施した。ラウドネス・ シャープネス・ラフネスの值を比較すると，3 種のポテ トチップス間に有意差があり（Fig. $9(\mathrm{~A}) \sim(\mathrm{C})$ ), 心理 音響評価量を用いて食感を客観的に評価できることが示 された。

\section{3 おわりに}

本稿では, 食品の「おいしさ」にかかわる食感の可視 化にあたり, “音”の重要性とその評価方法について紹 介した。このほかにも, 咀嚼時の音に関する研究事例と して, ヒトの咀嚼をさらにリアリテイ高く再現する装置 を用いた評価方法や，それぞれの食品・食感に特化した 評価方法等の報告がなされている。牧野ら ${ }^{22)}$ は, 人間 が骨伝導により咀嚼音を取得する仕組みを模倣し，アク リル歯・アクリル骨・左右ふたつの振動センサからなる システムを試作している。主成分分析から求めた破砕音 の定位感・広がり感は食感と高い相関を示し, 冷凍保存 したコロッケを用いてクリスピー感の特徵量も抽出して 
いる。また，西津 ${ }^{6,23)}$ は，天ぷら衣の微細構造が壊れ る際の破砕振動が小さなクラック振動の集合体であるこ と, その発生頻度がサクサク感の官能評価結果と高い相 関があることを示している。

人の咀嚼を模した装置を用いた破砕現象を，音や圧力 等の物理的指標から解析するというアプローチは客観性 が高いものの，官能評価結果（実感）との対応付けや特 徵量の抽出といった点では課題を有する。その課題を解 決するために，近年では食感評価に AI 技術を組み合わ せ, 特徵量の抽出や食感の判別に活用する事例も増えて きている。加藤ら ${ }^{24)}$ は, 破砕音と荷重のデー夕を用い て CNN モデルを構築し，スナック菓子 5 種を判別でき ると報告している。吉田ら ${ }^{25)}$ は，圧縮試験時に計測し た圧力の生データを用いて機械学習による食感分析を実 施しており，市販のポテトチップス 3 種を約 $80 \%$ の確 度で判別できると報告している。このように，食感評価 技術に異なる技術を組み合わせることによって，多様な 食品の評価や，官能評価試験における課題が解決される 可能性もある。

また，“音”による食感評価研究を社会実装する方向 性として, 咀嚼音の増強や呈示により, むしろ人の知覚 を変化させる試みも行われている。小泉ら ${ }^{26)}$ は, 咀嚼 音を提示できる「食感拡張装置」を試作し，ポテトチップ スやビスケットの食感知覚を変化させている。遠藤ら ${ }^{27}$ は, 筋電咀嚼音のフィードバックによって介護食の食感 が好ましく知覚される可能性を示している。今後, ウ工 アラブル端末等の進化にともない, 食感評価研究は“音” の活用によって積極的に人の感じ方を変化させ，「おい しさ」を増強する技術へと発展することも期待される。

\section{文 献}

1）高橋亮, 西成勝好, ぶんせき, 8, 388-394（2010）. (Takahashi, R. et al. Bunseki, 8, 388-394 (2010))

2) 柳本正勝, 日本調理科学会誌, 35, 32-36 (2002). (Yanagimoto, M. J. Cookery Sci. Jpn., 35, 32-36 (2002))

3）早川文代, 日本食品科学工学会誌, 60, 311-322 (2013). (Hayakawa, F. J. Jpn. Soc. Food Sci., 60, 311-322 (2013))

4）石橋賢, 深瀧創, 宮田一乘, 人工知能学会論文誌, 30, 229-236 (2015). (Ishibashi, K. et al. Trans. Jpn. Soc. Artif. Intell. 30, 229-236 (2015))

5）隅田孝, 四天王寺大学紀要，67，295-314 (2019). (Sumida, T. Shitennoji University Bulletin, 67, 295-314 (2019))

6）西津貴久, 日本調理科学会誌, 50, 127-132 (2017). (Nishitsu, T. J. Cookery Sci. Jpn, 50, 127-132 (2017))
7) Drake, B. K., J. Food Sci., 28, 233-241 (1962).

8) Vickers, Z. M., Wasserman, S. S., J. Texture Stud., 10, 319-332 (1980).

9) Vickers, Z. M., Carol, M. C. J. Texture Stud., 11, 291308 (1980).

10) Lee Iii, W. E., Deibel, A. E., Glembin, C. T., Munday, E. G., J. Texture Stud., 19, 27-38 (1988).

11) Lee, W. E., Schweitzer, M. A., Morgan, G. M., Shepherd, D. C., J. Texture Stud., 21, 165-178 (1990).

12) Dacremont, C., J. Texture Stud., 26, 27-43 (1995).

13) Dacremont, C., Colas, B., Sauvageot, F., J. Texture Stud., 22, 443-456 (1991).

14) Duizer, L. M., Campanella, O. H., Barnes, G. R. G., J. Texture Stud., 29, 397-411 (1998)

15) Zampini, M., Spence, C., J. Sens. Stud., 19, 347-363 (2004).

16）相良孝昭，佐伯剛，山口誠，日本食品工業学会誌，16, 350-354 (1969). (Sagara, T. et al. NIPPON SHOKUHIN KOGYO GAKKAISHI, 16, 350-354 (1969))

17) Seymour, S. K., Hamann, D. D., Transactions of the ASAE, 27, 1245-1250 (1984)

18) Sanz, T., Primo-Martín, C., Van Vliet, T., Food Res. Int., 40, 63-70 (2007).

19）豊島尊, 土屋欣也, 佐藤史明, 橘秀樹, 日本食品科学 工学会誌, 51, 388-394 (2004). (Toyoshima, T. et al. J. Jpn. Soc. Food Sci, 51, 388-394 (2004))

20）白澤聖一, 日本農芸化学会 2003 年大会講演要旨集, 東 京, 203 (2003). (Shirasawa, S. Annual Meeting of the Japan Society for Bioscience, Biotechnology, and Agrochemistry, 2003 (Tokyo), Abstract 203 (2003))

21）新谷勲, 丸山武紀, 今村正男, 牧野輝男, 松本太郎, 油化学, 19, 313-318 (1970). (Niiya, I. et al.J. Jpn. Oil Chem. Soc., 19, 313-318 (1970))

22) Makino, Y., Ono, N., Ando, S., Sano, F., Toba, S., Proceedings of the 41st SICE Annual Conference. SICE 2002, 4, 2163-2166 (2002).

23）西津貴久, 日本食品工学会誌，21，53-62（2020）。 (Nishitsu, T. J. Jpn. Food Eng. 21, 53-62 (2020))

24) Kato, S., Wada, N., Ito, R., Shiozaki, T., Nishiyama, Y., Kagawa, T., Future Internet, 11, 68 (2019).

25）吉田駿介, 武政誠, 人工知能学会全国大会論文集 第 34 回全国大会, 1F4OS2b03-1F4OS2b03（2020）。(Yoshida, S. et al. Proceedings of the Annual Conference of JSAI, 34th Annual Conference, 2020, 1F4OS2b03 (2020))

26）小泉直也, 田中秀和, 上間裕二, 稲見昌彦, 日本バーチャ ルリアリティ学会論文誌, 18，141-150（2013）。（Koizumi, N. et al. Transactions of the Virtual Reality Society of Japan, 18, 141-150 (2013))

27) Endo, H., Ino, S., Fujisaki, W., Appetite, 116, 493-501 (2017). 